\title{
All Together Now: Degree Completions!
}

\author{
Libby V. Morris
}

Published online: 13 April 2012

(C) Springer Science+Business Media, LLC 2012

The Complete College America (CCA) forces have swept across the nation and firmly landed in Georgia with the Complete College Georgia (CCG) initiative, supported by the Governor and led by the University System of Georgia's Office of Educational Access and Success in partnership with the Technical College System of Georgia. Founded in 2009, the nonprofit CCA aims to increase college completion rates, to increase job-related credentials, and to narrow the gap in college attainment for traditionally underserved populations. The Georgia initiative will build partnerships to focus on data and metrics, transforming remediation, restructuring delivery, and decreasing time to completion (see the url under resources). CCA is supported by heavy hitting foundations including the Gates Foundation, the Ford Foundation, the Carnegie Foundation of New York, the Kellogg Foundation, and Lumina. Georgia is one of 29 states to join CCA and is a recipient of a \$1 million grant for remediation projects at four institutions.

Complete College America is aligned with the federal emphasis on college completion and with Lumina ${ }^{\mathrm{TM}}$ Foundation's strategic direction to increase access to and success in college (postsecondary education). Lumina has identified this as its "big goal-to increase the percentage of Americans with high-quality degrees and credentials to $60 \%$ by the year 2025." Achieving GOAL 2025 will require an additional 23 million degrees over the next 12 years. The goal is premised on the need for an educated populace to succeed in the knowledge economy and to compete in the global economy. In the U.S., the percentage of population with a postsecondary credential or degree has held steady for 40 years, which yields a larger and larger gap between employment needs and individual preparation. Policy makers, governors, and educators all agree that we must do more to see that young adults graduate, gain skills to participate in the economy, and contribute to society and to their families and communities. In Georgia, an estimated $42 \%$ of the adult population has some level of college education. Reaching the $60 \%$ goal of attainment for certificate, associate, or baccalaureate degrees will require 250,000 additional degrees.

Data from the report Time is the Enemy by Complete College America (2011), show that six-year graduation rates across the states range from just around $35 \%$ to $72 \%$, while the rates for part-time students are significantly lower (approximately 8 to $39 \%$ ). Of great concern, and key to higher levels of completions, is the extremely low rate of completion for the population of part-time students, who now make up the bulk of college attendees. There

L. V. Morris $(\bowtie)$

Institute of Higher Education, University of Georgia, 102 Meigs Hall, Athens, GA 30602-6772, USA

e-mail: lvmorris@uga.edu 
are only two routes to more graduates: growing enrollments or more completions. Thus, increasing the percentage of degree holders nationally will require intensive effort over the next decade to graduate more of those who enroll. Student characteristics will not suffice as an answer for failure as the data show widely varying completion rates by institutions, even those institutions with similar student populations and selectivity. Hence, the emphasis is on completion, where governments, students, and institutions have already made significant financial (and time) investments toward earning a degree. States and institutions who sign on to CCA will set institution-specific degree and completion goals for each year.

To get started, we need better data and then a clearer understanding of where, when, and why we lose students. In the mid-1990s, the federal government defined graduation rates for full-time, first-time students over a four-year period and a six-year period. Two to three decades ago full-time students were the norm, and adult and part-time students were considered nontraditional. Today, the diversity in postsecondary education makes the sixyear traditional student completion rate less than useful. A unit-record form of tracking would better show all students as they move through various institutions of higher education. To track students better, the American Association of State Colleges and Universities (AASCU) and the Association for Public and Land-Grant Universities (APLU) began a voluntary system of accountability (VSA) in 2007, which yields a web report known as the College Portrait. A total of 300 of the 520 public institutions are members and voluntarily submit college enrollment and graduation data along with other campus specific information. In total, these institutions award approximately $70 \%$ of the U.S. baccalaureate degrees annually. VSA presents more granular institutional data about college completions, transfers, programs of study and so forth which is valuable, transparent information for potential students.

We increasingly know more about attainment rates across states and graduation levels by institutions. Across all institutional types, six-year completions, using the federal definition, range from high teens to just above $90 \%$. In Georgia, of the 35 public institutions, only three have rates at or above $60 \%$ - with the University of Georgia and Georgia Tech both at $80 \%$, which puts them in the top 30 of large research universities. An important part of understanding the problem will be having common metrics that will capture transfer students and part-time students who represent almost one-half of the college-going population. The National Governors Association Chair's Initiative (2011) adopted common metrics in 2010 as part of their report Complete to Compete, which makes college completion a priority.

It is encouraging, in many ways, to see such broad-based interest and support to bring about an increase in the number of degrees across the states. To attend college and leave without a degree and with a large loan may be among the worst scenarios for the individual and the society. However, in the counting and measuring, in the alignment of performance funding (or not), and in establishing carrots and sticks for completion, I hope the goal of high-quality degrees will not be forgotten. Degrees without substance do not move the individual or the society any farther down the road of productivity and achievement. The value of a degree should be linked closely to the value of the education. So, as we move down the path of higher degree completion, we must avoid value-less degrees; and we must avoid the devaluing (even more so) of the humanities and fine arts, which focus on personal growth and development. Perhaps a decade from now we will indeed see more students who have completed their degrees and better outcomes from these initiatives. More degrees will not result from merely refining the data, or writing new policies, or passing legislation. Teaching and learning are at the heart of course completion, which form the stepping stones for college completion. I look forward to the innovative steps that may be necessary to make both work better for students and institutions. 


\section{References}

Complete College America. (2011). Time is the enemy. Retrieved from http://www.completecollege.org/docs/ Time Is the Enemy.pdf

National Governors Association Chair's Initiative. (2011). Complete to Compete. From information to action: Revamping higher education accountability systems. NGA Center for Best Practicies. Retrieved from http://www.nga.org/files/live/sites/NGA/files/pdf/1107C2CACTIONGUIDE.PDF

\section{Resources}

Complete College America, http://www.completecollege.org/

Complete College Georgia, http://www.empoweredga.org/Articles/complete-college.html

Complete to Compete, http://www.subnet.nga.org/ci/1011/

Lumina $^{\mathrm{TM}}$ Foundation: http://www.luminafoundation.org/goal_2025/goal2.html

Voluntary system of Accountability: http://www.voluntarysystem.org/index.cfm?page=homePage 